\title{
A twenty year journey to understand how ATP activates guanylyl cyclase $A$ and $B$
}

\author{
Lincoln R Potter \\ From 6th International Conference on cGMP: Generators, Effectors and Therapeutic Implications \\ Erfurt, Germany. 28-30 June 2013
}

\begin{abstract}
Background
ATP was first shown to enhance the activity of natriuretic peptide (NP)-stimulated guanylyl cyclase (GC)-A in 1987 [1]. Later, NP-stimulation of GC-A and GC-B was reported to be dependent on ATP and a model was proposed where ATP binding to the kinase homology domain elevates maximal velocity of these enzymes [2]. Beginning in 1992, we demonstrated that GC-A and GC-B are phosphorylated and that phosphorylation is required for NP-stimulation [3-6]. Subsequently, ATP was shown to increase the phosphorylation and activity of GC-A in vitro, which explained why ATP is required for their activation [7]. Later, we demonstrated that ATP is not required for NP-dependent activation of GC-A and GC-B if phosphatase inhibitors are included in the assay and substrate levels are high [8]. Surprisingly, we found that ATP dramatically reduced the Michaelis constants (Kms) for GC-A and GC-B but had no effect on their maximal velocities [9].
\end{abstract}

\section{Results}

Recent studies have determined how ATP allosterically activates GC-A and GC-B [10]. In the absence of ATP, NPs activated these enzymes $>10$-fold in a positive cooperative manner. In the absence of NP, ATP shifted the substrate-velocity profiles from cooperative to linear but did not change the $\mathrm{Km}$. In the presence of NPs, ATP competed with GTP for binding to an allosteric site, which enhanced the activation of GCs by decreasing the $\mathrm{Km}$. Thus, NP binding was required for communication of the allosteric activation signal to the catalytic site. Concentration-response assays determined that the ability of ATP to activate GCs decreased and enzyme potency increased with increasing GTP concentrations, consistent with reciprocal regulation of the allosteric and catalytic sites. Point

Correspondence: potter@umn.edu

Department of Biochemistry Molecular Biology and Biophysics University of MinnesotaMinneapolis MN USA mutations in the purine-binding site of the catalytic domain abolished GC activity but not allosteric activation. Co-expression of inactive mutants produced half the activity expected for symmetric catalytic dimers. 2'deoxy-ATP and 2'deoxy-GTP were poor allosteric activators, but 2'-deoxy-GTP was an effective substrate, consistent with distinct binding requirements for the allosteric and catalytic sites.

\section{Conclusion}

GC-A and GC-B are asymmetric homodimers with distinct and reciprocally regulated catalytic and allosteric sites that bind GTP and ATP, respectively.

\section{Published: 29 August 2013}

\section{References}

1. Kurose H, Inagami T, Ui M: Participation of adenosine $5^{\prime}$-triphosphate in the activation of membrane-bound guanylate cyclase by the atrial natriuretic factor. FEBS Lett 1987, 219:375-379.

2. Chinkers M, Singh S, Garbers DL: Adenine nucleotides are required for activation of rat atrial natriuretic peptide receptor/guanylyl cyclase expressed in a baculovirus system. J Biol Chem 1991, 266:4088-4093.

3. Potter LR: Phosphorylation-dependent regulation of the guanylyl cyclaselinked natriuretic peptide receptor $\mathrm{B}$ : dephosphorylation is a mechanism of desensitization. Biochemistry 1998, 37:2422-2429.

4. Potter $L R$, Garbers DL: Dephosphorylation of the guanylyl cyclase-A receptor causes desensitization. J Biol Chem 1992, 267:14531-1454.

5. Potter $L R$, Hunter $T$ : Identification and characterization of the major phosphorylation sites of the B-type natriuretic peptide receptor. J Biol Chem 1998, 273:15533-15539.

6. Potter LR, Hunter T: Phosphorylation of the kinase homology domain is essential for activation of the A-type natriuretic peptide receptor. Mol Cell Biol 1998, 18:2164-2172.

7. Foster DC, Garbers DL: Dual role for adenine nucleotides in the regulation of the atrial natriuretic peptide receptor, guanylyl cyclase-A. J Biol Chem 1998, 273:16311-16318.

8. Antos LK, Abbey-Hosch SE, Flora DR, Potter LR: ATP-independent activation of natriuretic peptide receptors. J Biol Chem 2005, 280:26928-26932.

9. Antos LK, Potter LR: Adenine nucleotides decrease the apparent Km of endogenous natriuretic peptide receptors for GTP. Am J Physiol 2007, 293:E1756- E1763.
C Biomed Central

(c) 2013 Potter; licensee BioMed Central Ltd. This is an Open Access article distributed under the terms of the Creative Commons Attribution License (http://creativecommons.org/licenses/by/2.0), which permits unrestricted use, distribution, and reproduction in any medium, provided the original work is properly cited. 
10. Robinson JW, Potter LR: Guanylyl cyclases a and B are asymmetric dimers that are allosterically activated by ATP binding to the catalytic domain. Sci Sign 2012, 5:ra65.

doi:10.1186/2050-6511-14-S1-013

Cite this article as: Potter: A twenty year journey to understand how

ATP activates guanylyl cyclase A and B. BMC Pharmacology and

Toxicology 2013 14(Suppl 1):013.

Submit your next manuscript to BioMed Central and take full advantage of:

- Convenient online submission

- Thorough peer review

- No space constraints or color figure charges

- Immediate publication on acceptance

- Inclusion in PubMed, CAS, Scopus and Google Scholar

- Research which is freely available for redistribution

Submit your manuscript at www.biomedcentral.com/submit

() BioMed Central 